\title{
アコースティック・エミッションの波形を利用した コンクリートの軟化領域の推定法 \\ A METHOD OF DETERMINING SOFTENING ZONE IN CONCRETE USING ACOUSTIC EMISSION WAVEFORMS
}

\author{
篠 原 保 二*, 安 部 武 雄**, 古村福次郎*** \\ Yasuji SHINOHARA, Takeo ABE and Fukujiro FURUMURA
}

\begin{abstract}
An acoustic emission (AE) testing is useful for detecting the damage within cementitious materials in real time. Based on the time differences between detections of an AE event at different transducers, its source can be located. Sources of AE activity were studied for plain-mortar, concrete and model-concrete specimens loaded in three-point bend. To locate AE sources precisely, the arrival time was determined from the first motion of the waveform and the spectral analysis was carried out based on the maximum entropy method. The results show that $\mathrm{AE}$ events from the tip in the softening zone have higher frequency components $(250-450 \mathrm{kHz})$ besides the frequency components in the range of $100-200 \mathrm{kHz}$ which all $\mathrm{AE}$ events have. By picking the $\mathrm{AE}$ events with higher frequency components, it is possible to evaluate the extent of the damage in concrete-like materials more clearly.
\end{abstract}

Keywords: concrete, acoustic emission, AE source, softening zone, spectral analysis, maximum entropy method コンクリート, アコースティック・エミッション, $\mathrm{AE}$ 源, 軟化領域, スペクトル解析, 最大エントロピー法

\section{1.はじめに}

固体材料が変形もしくは破壊する際には、内部に蓄積 されたエネルギーが急激に解放されるため、その一部は 過渡的な弾性波となって伝播する。その弹性波がアコー スティック・エミッション (Acoustic Emission、以後 $\mathrm{AE}$ と略す)である。

$\mathrm{AE}$ は、試験体内部のダメージの状況を、リアルタイム で測定できる方法として有望視されており、多数の研究 が報告されている1)-5)。AE 信号は、主に次のように解 析されている。

1）外力による内部のダメージの様子を知るために、 $\mathrm{AE}$ 発生頻度を計測する。

2）限界エネルギー解放率を決定するために、AEエネ ルギーを使用する。

3）異なる荷重段階で生じるダメージのメカニズムの相 違を区別するために、 $\mathrm{AE}$ 信号の周波数成分、振幅、 立ち上がり時間を使用する。

* 東京工業大学工業材料研究所 助教授. 工博

** 東京工業大学工業材料研究所 助教授 $\cdot$ 工博 東京工業大学工業材料研究所 教授・工博
4）複数個の $\mathrm{AE}$ センサーに到達する同一 $\mathrm{AE}$ 信号の時 間差から、 $\mathrm{AE}$ 発生源を標定し、クラックの進展や 軟化頒域の大きさを検討する。

5） AE の波形解析により、マイクロクラックの大きさ、 方向、タイプを識別する。

上記 4),5) の解析法は、コンクリート内部の破壊メカ ニズムを知る上で有力な方法である。しかしながら、複 数個の $\mathrm{AE}$ センサーに到達する同一 $\mathrm{AE}$ 信号の時間差か ら、 $\mathrm{AE}$ 発生源を標定する場合、その標定位置は、実際に 観察されるひび割れを中心に、かなりランダムに分布す る。その原因として、 $\mathrm{AE}$ 信号の到達時間をしきい值を超 えた時間とした場合、真の到達時間より遅れることが考 えられる。例えば、図ー1において $\mathrm{AE}$ 波形の周波数を $200 \mathrm{kHz}$ とすると、 $\Delta t$ は約 $5 \mu \mathrm{s}$ となり、 $\mathrm{AE}$ の伝播速度 を $4000 \mathrm{~m} / \mathrm{s}$ とすると、約 $20 \mathrm{~mm}$ の標定䛊差を生じる。

本研究では、AE 発生源の位置標定精度を高めるために、 図ー 1 に示すような各AE 波形の初期微動開始時間より真 Assoc. Prof., The Research Laboratory of Engineering Materials, Tokyo Institute of Technology, Dr. Eng. Assoc. Prof., The Research Laboratory of Engineering Materials, Tokyo Institute of Technology, Dr. Eng. Prof., The Research Laboratory of Engineering Materials, Tokyo Institute of Technology, Dr. Eng. 
の $\mathrm{AE}$ 到達時間を決定し、さらに、 $\mathrm{AE}$ 波形のスペクトル 解析を行い、そのスペクトルパターンを比較することに よって、ダメージに起因したと考えられる AE 信号を識 別し、軟化領域の進展および大きさを推定する。

また、先の報告6)では、軟化領域における応力伝達機 㯨は、クラック先端前方の不連続なマイクロクラック、 あるいはクラック先端後方の蛇行したクラック問におけ る摩擦㧍よび粗骨材によるブリッジングに起因すること が明らかになり、その力学的特性を伝達応力と仮想ひび 割え幅の関係でモデル化した。しかしながら粗骨材によ るクラック拘束とは実際にどんなものなのか、あるいは どのように引張応力を伝達できるのかということに関し ては研究例が少ない3),7)。それ故、粗骨材のクラック拘 束のメカニズムを解明するための一助として、円柱状の 疑似粗骨材を含む簡単なモデルコンクリート試験体を用 いて、クラック進展に及ぼす骨材の影響について検討す る。本報は、文献8)に、実験と考察を追加し、まとめた ものである。

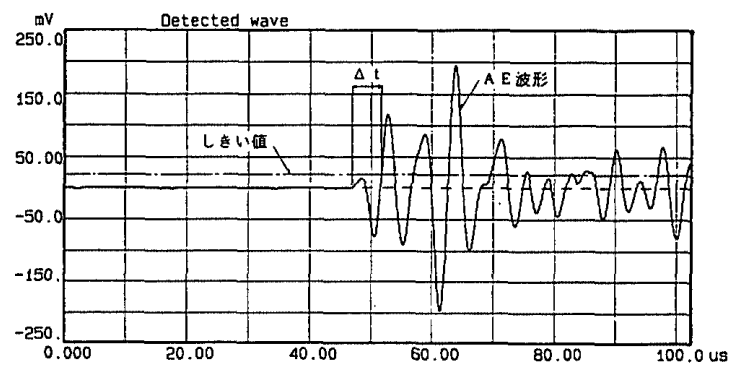

図一1 しきい値と $\mathrm{AE}$ 信号到達時間の関係

\section{2. データ処理方法}

\section{1 計測装置}

$\mathrm{AE}$ の計測装置は、受信用センサー、増幅器、収集・選 別・記録装置によって構成されている。 $\mathrm{AE}$ 計測に用いた センサー、プリアンプ、ローカルプロッセサ、ウェーブ メモリの主な仕様および設定值を表ー1に示す。

\section{表ー1 A E 計湘装置の仕様および設定值}

\begin{tabular}{|c|c|c|}
\hline センサー & 共振周波数 & $140 \mathrm{kHz}$ \\
\hline \multirow{2}{*}{$\begin{array}{c}\text { プリアンブ } \\
.\end{array}$} & N仿X7イny- & $50 \mathrm{kllz}$ \\
\hline & 堿幅 & $40 \mathrm{~dB}$ \\
\hline \multirow{6}{*}{$\begin{array}{l}\text { ローカル } \\
\text { プロセッサ }\end{array}$} & 增幅 & $20 \mathrm{~dB}$ \\
\hline & しきい值 & $0.2 \mathrm{~V}$ \\
\hline & $\overline{\bar{\tau}}^{\prime}$ クドタ亿 & Imsec \\
\hline & コインシデン & $32 \mu \mathrm{sec}$ \\
\hline & $t^{2}-94-9414$ & $64 \mu \mathrm{sec}$ \\
\hline & $y y^{*} n-: / a \%$ & $64 \mu \mathrm{sec}$ \\
\hline \multirow[t]{4}{*}{ ウェーフメモリ } & 振幅 & $1 v_{p-p}$ \\
\hline & $4 \because 7^{*} y \times 7^{\circ}$ & $100 \mathrm{nsec}$ \\
\hline & 波形曼 & $1 \mathrm{k}$ word \\
\hline & $\vec{F}^{\circ}$ 似 & -512 word \\
\hline
\end{tabular}

\section{2 スペクトル解析法}

本解析に用いたスペクトル推定法は、最大エントロ ピー法（以後、MEM と略す）である。信号処理におい て测定できるデータの数は有限であり、十分大きなラグ に対する自己相関関数は未知である。それ故、高速フー リエ変換（以後、FFT と略す）によるスペクトル推定法 では、データを補って処理するのである。一方 MEM で は、未知のデータはできるだけ未知のままに、すなわち、 信号の情報エントロピーをできるだけ大きくして、测定 できるラグの自己相関関数からスペクトルを推定する。 MEM は、FFT と比較すると、短いデータからもスペク トルの推定が可能であり、その分解能が極めて高いとい う優位性をもっている。また低い次数で解析を行うこと により、スペクトルが平滑化され、波形の特性を分類す ることができ、本研究の目的に適した方法であると考え られる。以下に、MEM の考え方を要約する99)。

最大エントロピーの概念をスペクトル解析に適用する 場合、正規確率分布をもつ時系列のエントロピーH（正 確にはエントロピー密度 $h)$ と時系列のスペクトル $\mathrm{P}(\mathrm{f})$ の間の次の関係式を利用する10), 11)。

$$
h=\frac{1}{4 f_{N}} \int_{-f_{N}}^{f_{N}} \log P(f) d f+\frac{1}{2} \log 2 f_{N}
$$

ここで、 $f_{N}$ は Nyquist 周波数であり、(1)式は、時系列の エントロピー密度が、その時系列のスペクトルの対数を 周波数について、 $f_{N}$ の範围で積分した量であることを示 している。スペクトルを計算するのには、スペクトルと 自己相関 $\phi(k)$ の関係（Wiener-Khintchineの関係式）

$$
P(f)=\Delta t \sum_{k=-\infty}^{\infty} \phi(k) \exp (-i 2 \pi f k \Delta t)
$$

を用いる。ここで、 $\Delta \mathrm{t}$ はデータのサンプリング間隔であ る。既知の自己相関 $\phi(0) 、 \phi(1) 、 \cdots \phi(m-1)$ に対しては (2) 式が成立するという制約のもとで、未知の自己相関に 対して (1) 式を最大にするように推定するのが、MEMの スペクトル推定法である。この推定法は、未知の情報に 対しては最大の不確定さを表すが、既知の情報に対して は整合性がある。条件付き変分法により、MEM スペク トルに対する次式が得られる10), 11)。

$$
P(f)=\frac{P_{m}}{2 f_{N}\left|1+\sum_{j=1}^{m-1} \gamma_{j} \exp (-i 2 \pi f j \Delta t)\right|^{2}}
$$

ここで、係数 $\gamma_{j}$ は予测虽差フィルター、 $P_{m}$ はこの フィルターからの平均出力であり、Burgアルゴリズム12) によって効率的に計算できる。 


\section{3. 実験方法}

\section{1 試験体}

試験体はモルタル、コンクリートおよび多孔質のアル ミナセラミックスを疑似粗骨材としたモデルコンクリー トの三種類のである。さらにモデルコンクリートは、疑 似粗骨材（厚さ $9 \mathrm{~mm}$ のプレートまた㥀径 $15 \mathrm{~mm}$ の円柱 棒）の配置により、図ー2に示す 6 タイプを用意した。 アルミナセラミ:ックスの化学組成および物理的性質を表 -2に示す。アルミナセラミックスは、吸水率が大きい ため、打設前に水に浸しておいた。また、アルミナセラ ミックスとモルタル間の 4 週曲げ試験による付着強度は、 約 $18 \mathrm{~kg} / \mathrm{cm}^{2}$ であり、安山岩 (約 $14 \mathrm{~kg} / \mathrm{cm}^{2}$ ) と花こう岩 (約 $22 \mathrm{~kg} / \mathrm{cm}^{2}$ ) の付着強度のほぼ中間の值である。

試験体の調合を表一 3 に示す。試験体は、100x100x400 $\mathrm{mm}$ の銅製型枠で製作したが、打設から脱型迄の間、疑似 粗骨材が正確な位置を保持できるように、テンプレート を用いて打設した。約 24 時間後に脱型、その後 $20^{\circ} \mathrm{C} の$ 恒 温水槽に移して水中養生を行った。試験体は材命約 1 年 で水槽から取り出し、AE 波形の減衰をできるだけ抑える ため、打設方向と直交する方向にダイヤモンドカッター で切断することによって幅を半分にした。したがって試 験体寸法は、約 $50(\mathrm{~W}) \times 100(\mathrm{H}) \times 400(\mathrm{~L}) \mathrm{mm}$ である。深さ $50 \mathrm{~mm}$ のノ.ッチは、モルタルおよびコンクリートの場合 は厚さ $1.2 \mathrm{~mm}$ のダイヤモンドカッターで導入し、モデル コンクリートの場合は、厚さ $0.8 \mathrm{~mm}$ のオイルを塗布した ステンレスプレートを打設時に挿入することによって導 入した。個々の試験体名は以下のように表す。

\section{$\mathrm{X}$ 一（試験体番号）十Tまたは B}

Xは、モルタルおよびコンクリートの場合、それぞれ MT およびCT とし、モデルコンクリートの場合、図ー2に示 す各タイプの記号 (PL、Al、A2、S3、S4、S5) とする。 最後の $\mathrm{T}$ または B は、綐割りした試験体が打設時の上半 分または下半分を表す。

表ー2 アルミナセラミックスの化学組成および物理的性質

\begin{tabular}{|c|c|c|c|}
\hline 化学組成 & $(\%)$ & 物理的性質 & \\
\hline $\mathrm{Al}_{2} \mathrm{O}_{3}$ & 90.0 & 比 重 & 2.6 \\
\hline $\mathrm{SiO}_{3}$ & 7.2 & 吸水率 (\%) & 13.0 \\
\hline $\mathrm{Na}_{2} \mathrm{O}_{3}$ & 0.5 & 酎压強度 $\left(\mathrm{kg} / \mathrm{cm}^{2}\right)$ & 860.0 \\
\hline $\mathrm{MgO}$ & 2.0 & 曲版強度 $\left(\mathrm{kg} / \mathrm{cm}^{2}\right)$ & 280.0 \\
\hline $\mathrm{Fe}_{2} \mathrm{O}_{3}$ & 0.1 & 䓡伝導率 $\left(\mathrm{Kcal} / \mathrm{mh}^{\circ} \mathrm{C}\right)$ & 3.0 \\
\hline & & 熱膨張係数 $\left(10^{-4}\right)$ & 5.8 \\
\hline
\end{tabular}

表 -3 . 試験体の調合

\begin{tabular}{|l|c|c|c|c|}
\hline$\cdot$ & $\begin{array}{c}\text { 水 } \\
\left(\mathrm{kg} / \mathrm{m}^{3}\right)\end{array}$ & $\begin{array}{c}\text { セメント } \\
\left(\mathrm{kg} / \mathrm{m}^{3}\right)\end{array}$ & $\begin{array}{c}\text { 細骨材 } \\
\left(\mathrm{kg} / \mathrm{m}^{3}\right)\end{array}$ & $\begin{array}{c}\text { 粗骨材 } \\
\left(\mathrm{kg} / \mathrm{m}^{3}\right)\end{array}$ \\
\hline $\begin{array}{l}\text { モンクリート } \\
\text { モデ・N }\end{array}$ & 194 & 353 & 700 & 1054 \\
\hline
\end{tabular}

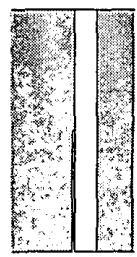

(1) PL



(2) $\mathrm{Al}$

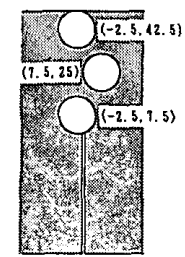

(3) A2



(4) $\mathrm{S} 3$

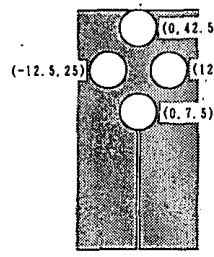

(5) $\mathrm{S} 4$

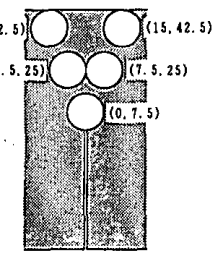

(6) S5
図-2 疑似粗骨材 (9mm厚プ・レートと $15 \mathrm{~mm}$ 直径归舛ー) による モデネコンクリートの種類と記号（図中の数值は、1ッチ先端を 原点とした場合のシリタダーの中心座標 $(\mathrm{mm})$ )

\section{$3: 2$ 実験方法}

載荷方法は、インストロン型 25ton 試験機を用いて、 一定の変位速度 $(0.005 \mathrm{~mm} / \mathrm{min}$.) で 3 点曲げ載荷を行った。 荷重は $0.2 \mathrm{~kg}$ 感度のロードセルで、また、鈶直変位 3 简 所は $1 / 2000 \mathrm{~mm}$ 感度の変位計を用いて测定した。夷験装 置を図ー3に示す。また、実際のモデルコンクリート試 験体の載荷の様子を写真ー 1 に示す。 $\mathrm{AE}$ センサーを試験

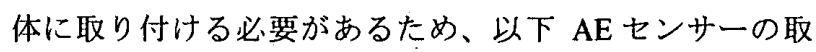
り付け方法について述べる。

山田ら2)仗、 $\mathrm{AE}$ の減衰特性に及ぼすセンサーの装着方 法の影響を調べるための実験を行い、瞬間接着剤でセン サーを直接試験体に装着した場合が最も減衰が少なく、 最適な方法であると述べている。しかしながら瞬間接着 剤を用いる場合、取り外しの際、センサーを壊す恐れが ある。それ故、本実験では、瞬間接着剂と同じような密 着性が得られる感熱接着郕を用いてセンザーを坟着した。

$\mathrm{AE}$ 発生源の三次元位置標定を行う場合、同一平面上に ない 4 個以上のセンサーが必要となるが、センサーの配 置が三次元位置標定精度に影響を及ぼすと考えられる。 そこで図ー4に示す 4 タイプのセンサー配置に対し、 シャープペンシルの芯折による疑似 AE を用いて、三次 元位置標定精度の検討を行った。疑似 $\mathrm{AE}$ は予測される クラック経路上に入力し、その標定結果を図ー5,6に示 す。ただし、AE 伝播速度は、疑似 $\mathrm{AE}$ を用いて测定した

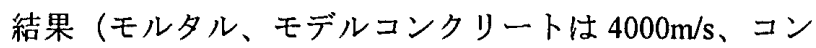
クリートは $4500 \mathrm{~m} / \mathrm{s}$ ）を使用している。図ー5からわかる ように、標定結果は、TYPEー3、4より $\mathrm{AE}$ 発生源に近い 配置となる TYPEー1 、2 のほうが良く一致している。さ らに図-6から、TYPE-1 は試験体上面で、TYPE-2 は 試験体背面で誤差が大きくなる傾向があるが、その他の 誤差は 1〜2mm 以内である。それ故本実験では、TYPE1 または 2 のセンサー配置で AE 信号を検出した。 


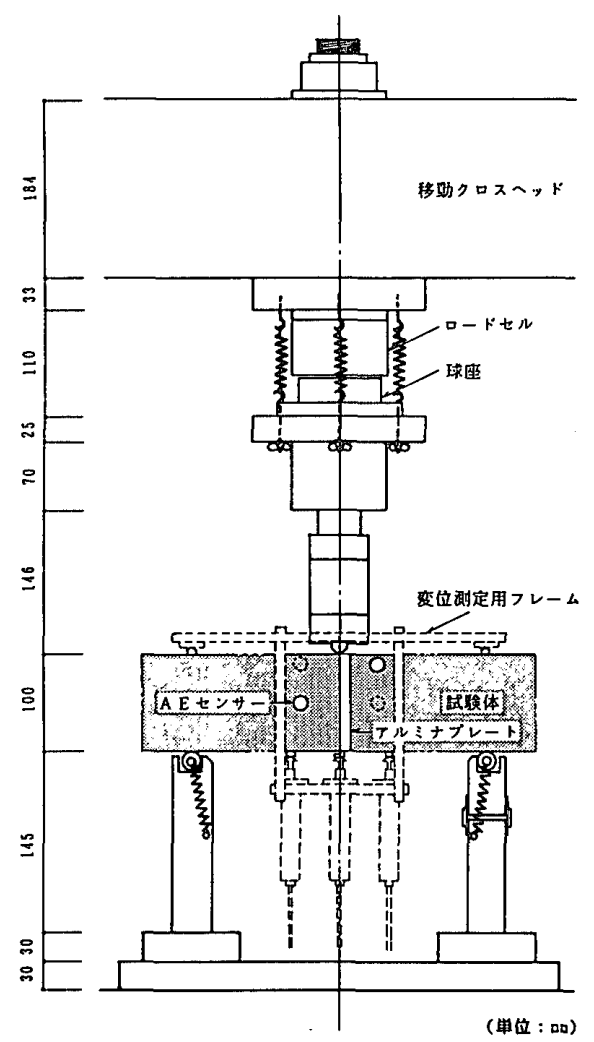

図-3 実験装置

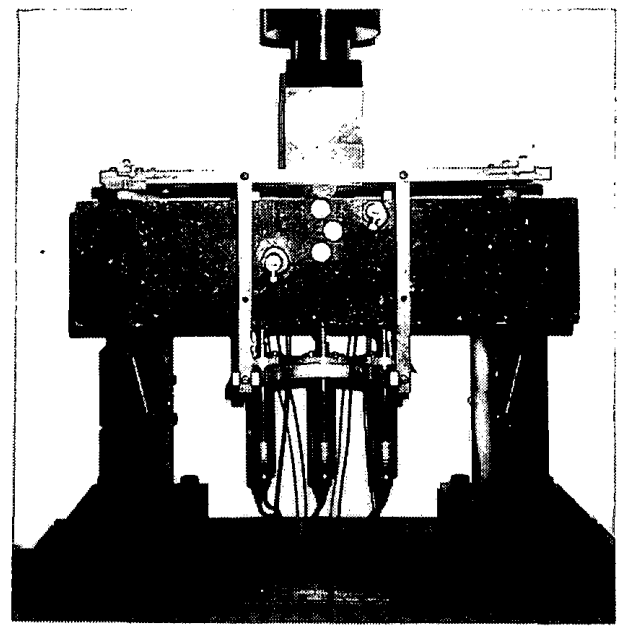

写真 $-1 \quad$ A2 型試験体と載荷装置

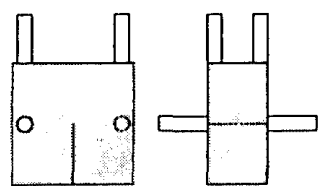

(1) TYPE-1

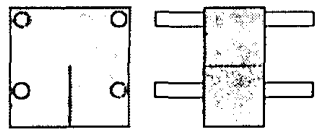

(3) TYPE-3

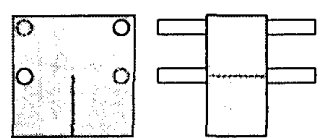

(2) TYPE-2

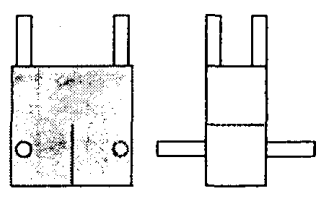

(4) TYPE-4
図 -4 三次元位置標定精度検討用のセンサー配置

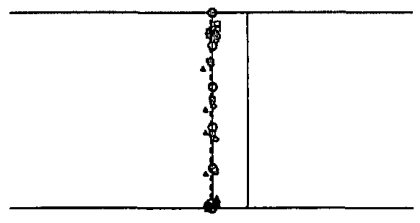

O: Correct polnts

Type-1 sensor setting

Evaluated points by

Type-2 sensor sottin

Tyaluated points by

Trec-s sensor setting

Type-4 sensor setting
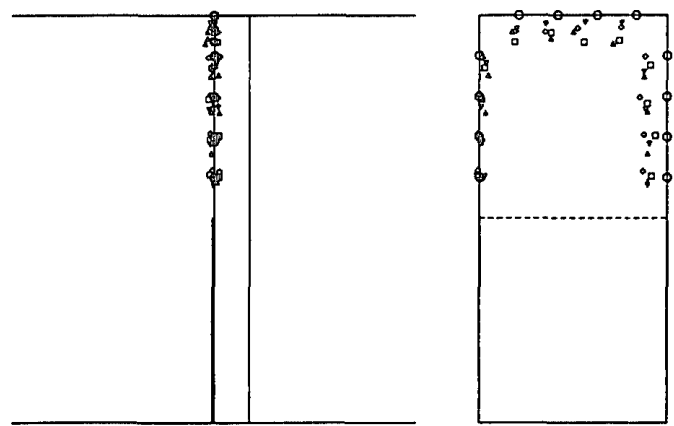

図ー5 各種センサー配置による AE 源位置標定結果 : PL-61B

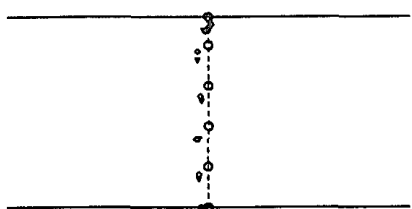

$0:$ Cortoct Doints $O$ : Evaluated poinis by : Evaluated poinis by Type-2 sensor soetcing


図-6 AE 源位置標定結果 (TYPE-1 and TYPE-2) : MT- B

\section{4. 実験結果およひ考察}

4.1 荷重一変位曲線

本実験により得られた荷重一変位曲線を図ー7〜11に 示す。図ー7から、プレート型のモデルコンクリートの 荷重一変位曲線は、個々の圾験体によって大きな相違が みられる。これは、個々の試験体の破断面の相違による （写真－2）。耐力の大きな PL-23B は、アルミナプレー トの半分以上にモルタルが付着した破壊面となっている が、耐力の小さな PL-23T の破罱面は、モルタルはほと んど付着していない。図-8,9 から、円柱型の疑似粗骨 材を用いたモデルコンクリート試験体は、一般に、打設 時下半分の試験体（試験体名の最後が B ）のほうが、上 
半分の試験体（試験体名の最後が $\mathrm{T}$ ）より耐力は大きく なっているが、最大耐力後の挙動は、よりなめらかな下 に凸のモルタルに近い举動となる。この原因も、両試験 体の破断面の相違による（写真－2）。上半分の試験体は、 モルタルと疑似粗骨材の境界面に沿ってクラックが進展 し、破壊に至っている。一方、下半分の試験体は、モル タルと疑似粗骨材の付着強度が高く、境界面よりモルタ ルの中を進展するクラックが多くなり、よりなめらかな 破壊面を形成している。したっがて、モデルコンクリー トに対して、定量的な考察を行うためには、破壊面の詳 細な検討が必要になる。しかしながら、これらの図は骨 材によるクラック拘束挙動を、定性的に説明していると いえる。すなわち、クラックが疑似粗骨材に到達した場 合、骨材を迁回してクラックがさらに進展するためには、 より多くのエネルギーが必要になる。それ故、最大耐力 後において、プレート型のモデルコンクリートにはない 上に凸の曲線がみられるようになり、図ー11に示すコン クリートの荷重一変位曲線に近づく。本モデルコンク リート試験体は、ノッチの先端に骨材が存在しているた

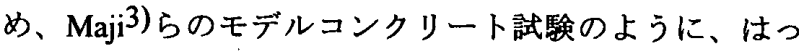
きりした二つのピークは現れなかった。しかし初期㴊性 はモルタルとほぼ同じであるが、最大荷重の 60〜80\%の 荷重で夙性の低下が生じ、不連続な曲線となっている。 この荷重一変位曲線の不連続性は、4 週および 1 年で実 験を行った全ての試験体（A型、S 型）に対して見られ

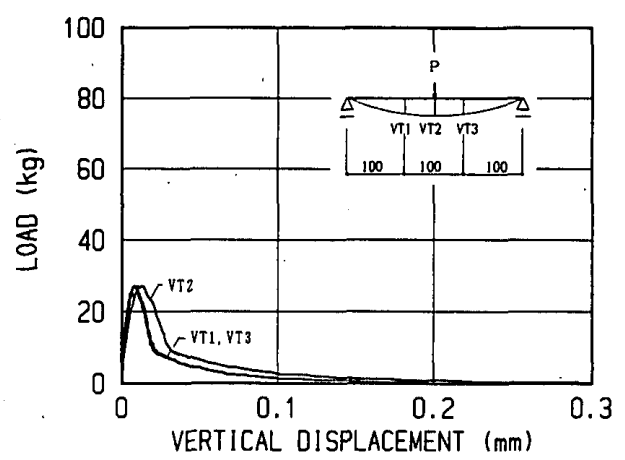

(1) PL-23T

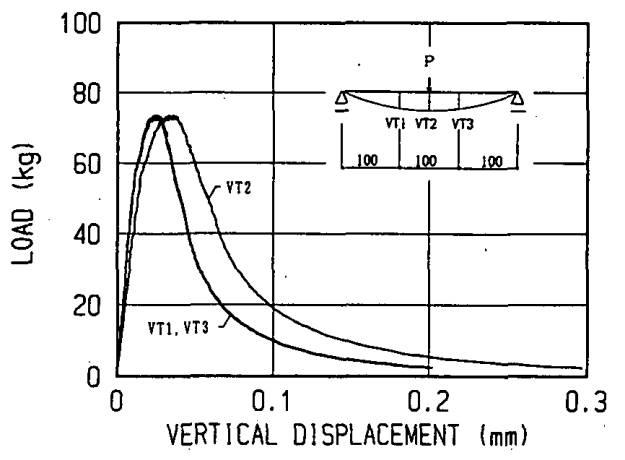

(2) PL-23B

図-7 荷重一変位曲線：PL-23T/PL-23B
た現象であるため、ノッチ先端の疑似粗骨材がその挙動 に大きく影響していると考えられる。すなわち、疑似粗 骨材がモルタルと完全に付着している間は、疑似粗骨材 の㴊性が支配的となるが、両者の境界面の最弱部に損傷 が起きはじめると、モデルコンクリートは一般のコンク リートと異なり、その境界面が全幅貫通しているため、 連続的にその境界面に損傷が起こり、一時的に荷重を保 持したまま、変位が增大寸る現象となる。

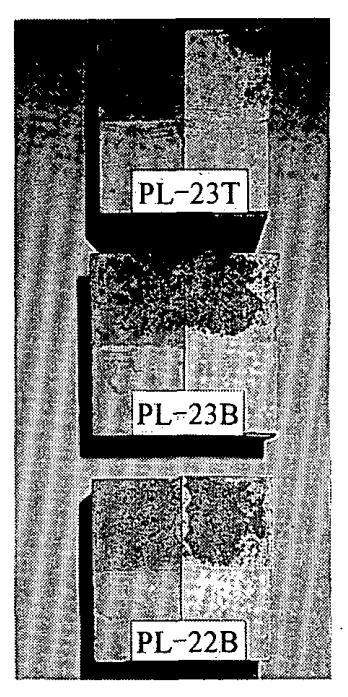

(1) PL 型試験体の破塄面

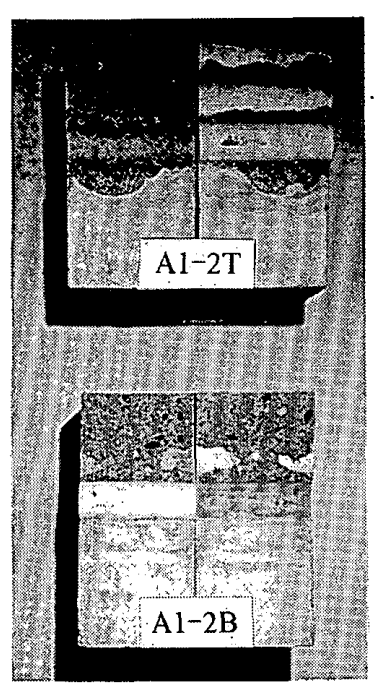

（2）Al 型試験体の破壊面 写真-2 モデルコンクリートの破壊面の例

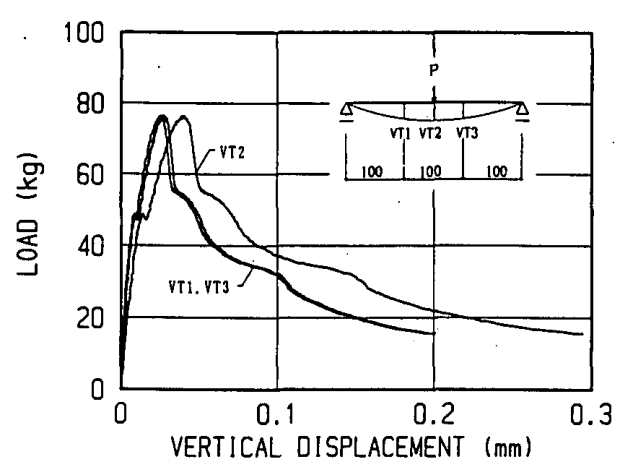

(1) $\mathrm{Al}-2 \mathrm{~T}$

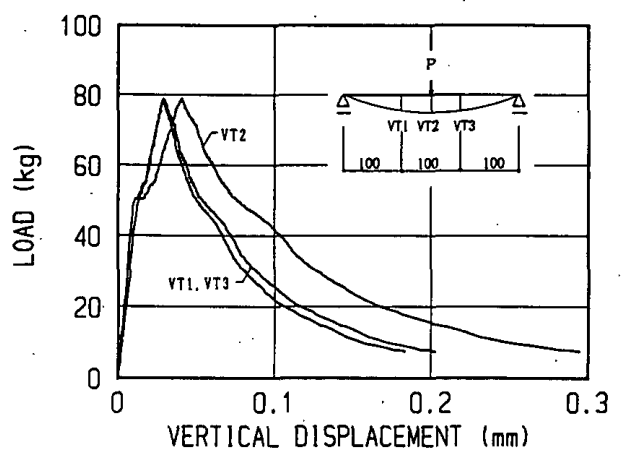

(2) $\mathrm{Al}-2 \mathrm{~B}$

図-8 荷重一変位曲線：Al-2T/A1-2B 


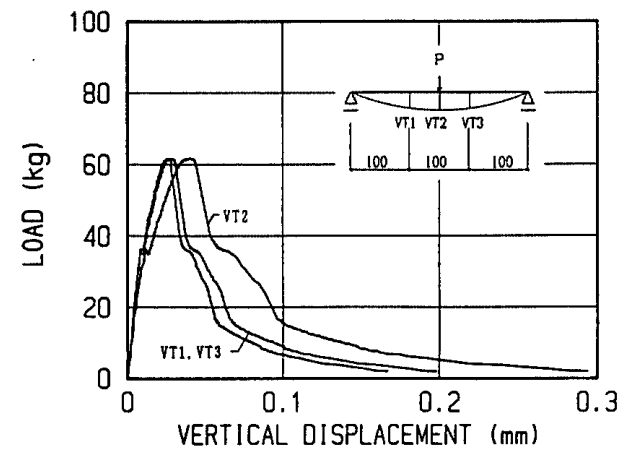

(1) $\mathrm{S} 5-2 \mathrm{~T}$

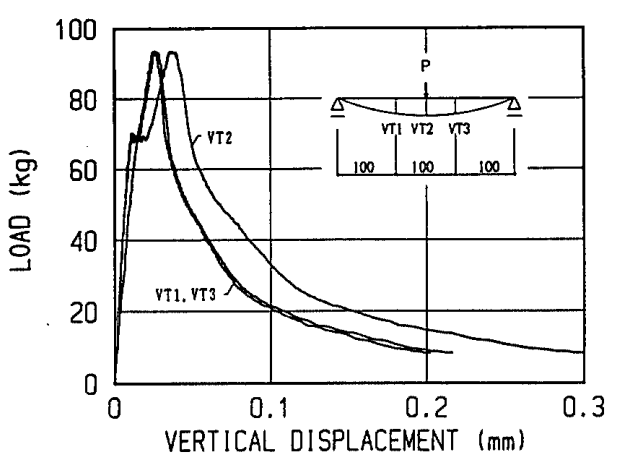

(2) $S 5-2 B$

図-9 荷重一変位曲線：S5-2T/S5-2B

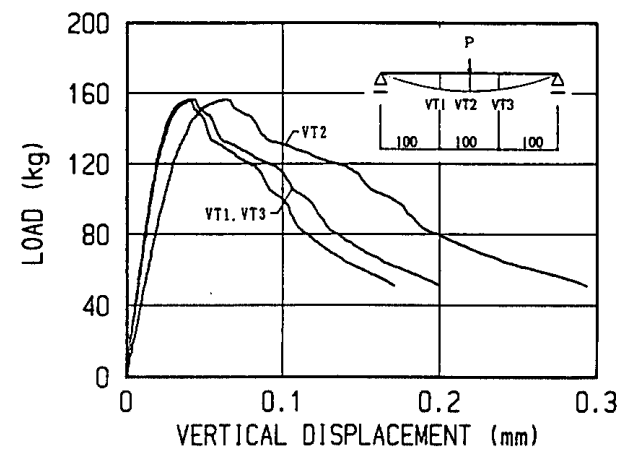

(1) $\mathrm{CT}-\mathrm{T}$

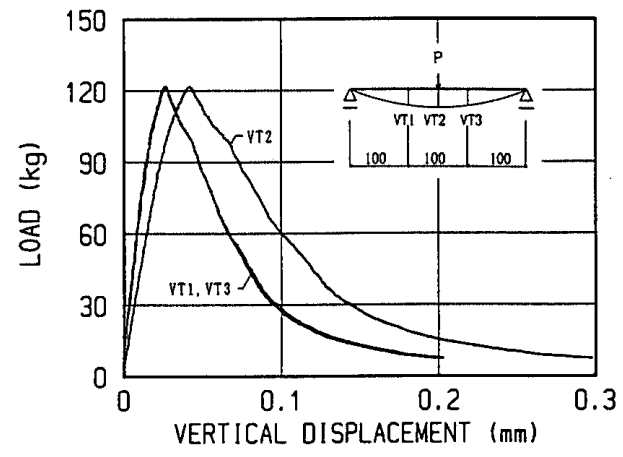

(1) $\mathrm{MT}-\mathrm{T}$

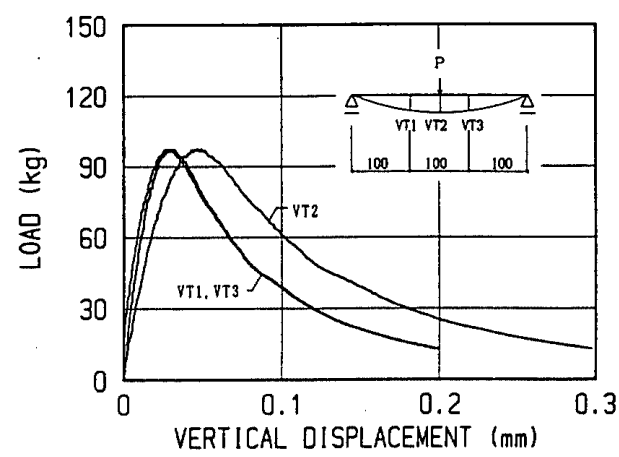

(2) MT-B

図-10 荷重一変位曲線：MT-T/MT-B

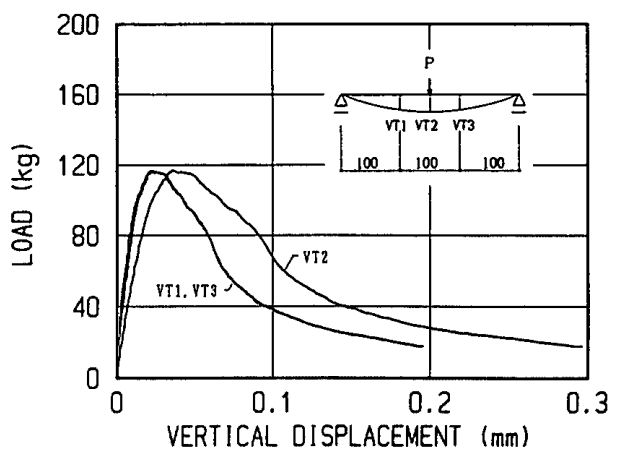

(2) $\mathrm{CT}-\mathrm{B}$

図-11 荷重一変位曲線：CT-T/CT-B

\section{2 三次元位置標定}

（1）プレート型モデルコンクリート

三次元位置標定を行った結果を図ー 12 に示す。標定位 置は、破壊面（ノッチのほほ延長面）を中心にかなりば らついている。そこで、しきい值を超えてからの 512 個 $/ 1$ 波形のディジタルデータについて、2.2 節で述べた $\mathrm{AE}$ 波形解析を行った。MEMの欠点は、予測誤差フィル ターの打ち切り次数（または項数） $\mathrm{m}$ を決定する合理的 な基準のないことであった。しかし、MEMと自己回帰式 (以後、AR と略す) との関係が明らかにされたことから、 ARについての赤池 13), 14) の final prediction error (FPE) によって、m を決定できる。実際にはFPEがはっきりし た極小値を示さない場合があるので、最適ラグ $\mathrm{m}$ は次の
籁囲以内で FPE を最小にするように選ぶことが多い。

$$
\mathrm{m}<(2 \sim 3) \sqrt{N}
$$

本解析では、 $\mathrm{N}=512$ であるから、m は 45〜68 以下とな る。一般に次数 $\mathrm{m}$ が小さくなると、スペクトルはなめら かになる。 $\mathrm{m}$ を10、30、50と変えたときのスペクトルの 変化の様子を、FFTによるスペクトルと一緒に図ー13に 示す。本解析では、スペクトルパターンの分類を容易に するために、 $\mathrm{m}=30$ の MEMによってスペクトルを推定 する。

次数 30 でMEM 解析を行った結果、得られた代表的な スペクトルパターンを、0〜 $512 \mathrm{kHz}$ の範囲で図ー14 に示 す。 $\mathrm{AE}$ 源の三次元位置標定の結果（図－12）加、 $150 \mathrm{kHz}$ 付近と $250-450 \mathrm{kHz}$ の 2 简所にピークを持つ $\mathrm{AE}$ 
波形は、破壊面のその時点におけるほぼ最上位置からの 信号であることがわかった。ままた、150kHz 付近に 1 箅所 だけピークを持つ $\mathrm{AE}$ 波形は、実際の破壊面以外の位置 および破壊面ではあるがその時点の最上位置より下側か らの信号であった。したがって、2 箘所にピークを持っ
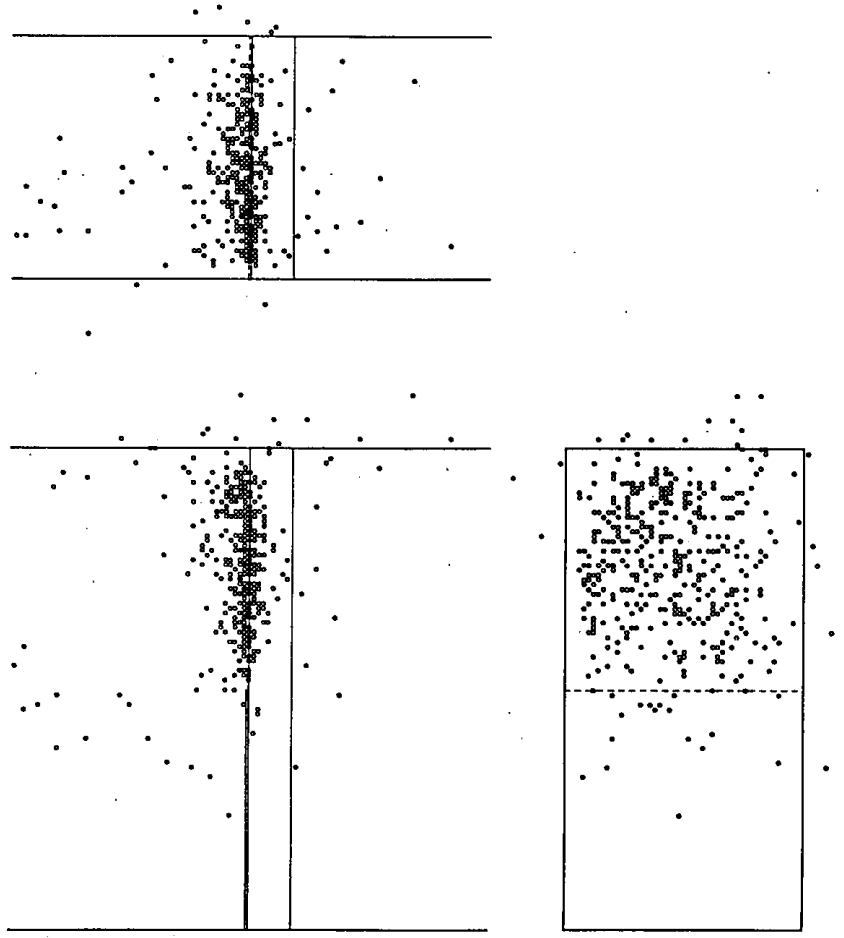

図-12 3 次元位置標定結果（全データ）:PL-22B

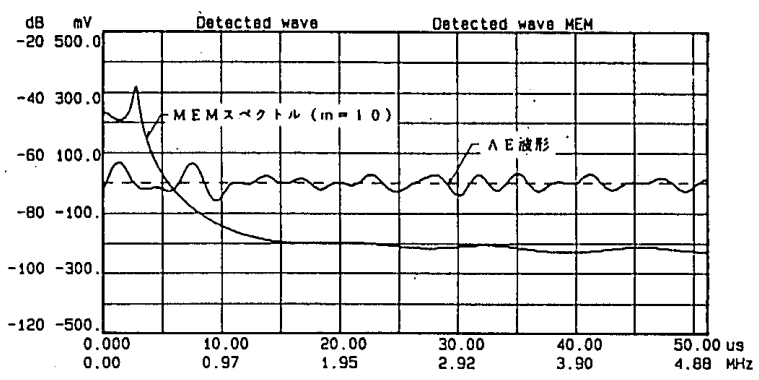

(1) MEMスペクトル $(m=10)$

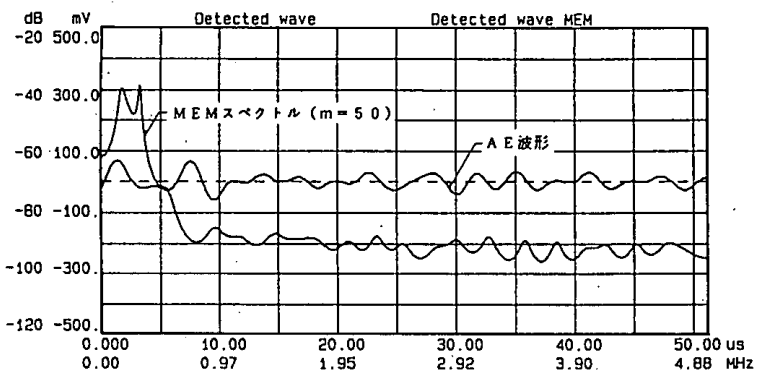

(3) MEMスペクトル $(m=50)$
$\mathrm{AE}$ 波形は処女破壊に対応する信号であると考えられ、こ れらの信号に対する AE 源を取り出すと、軟化領域の進 展挙動をより明確に検討することができる。図ー15にそ の進展挙動を：各荷重段階每に示す。図ー15 から、PL22B 試験体の軟化領域は、破壊面の左下より右上へ進展

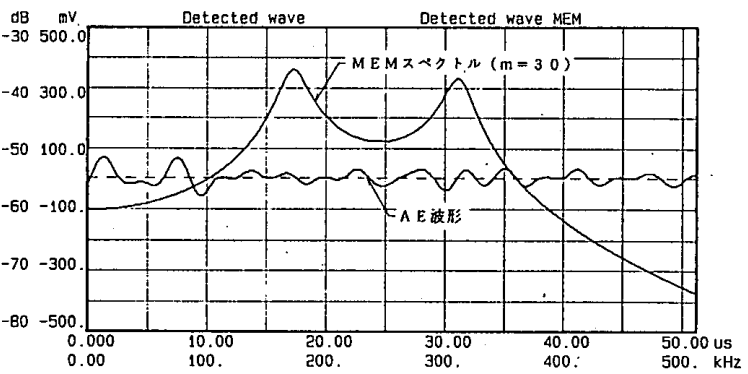

(1) MEM スペクトルに2 個のピークをもつ AE 波形

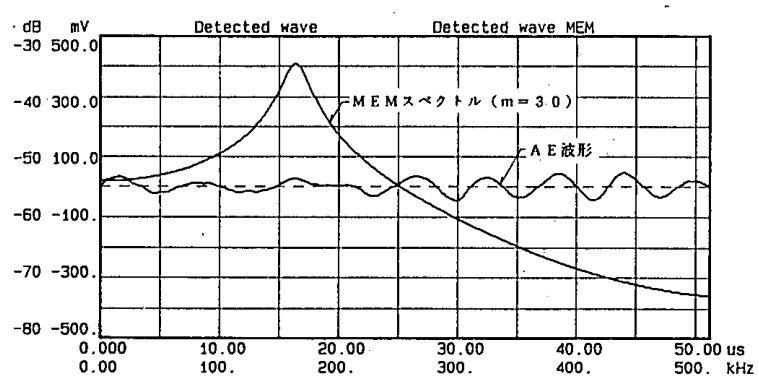

(2) MEM スペクトルに 1 個のピークをもつ AE 波形 図-14 MEM $(M=30)$ にる代表的なスペクトルパターン

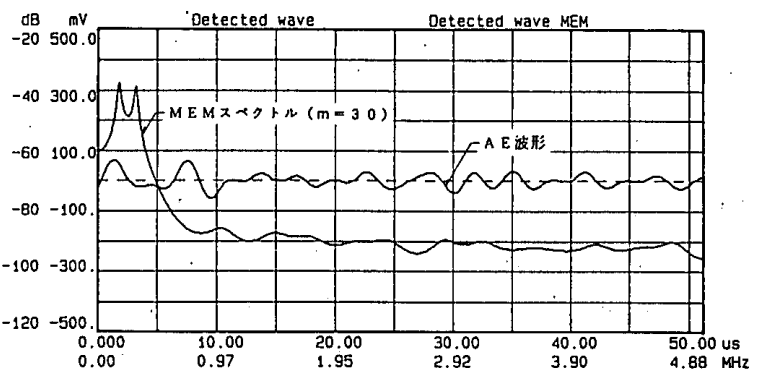

(2) $\mathrm{MEMスペクトル}(\mathrm{m}=30)$



(4) F F Tスペクトル

図-13 MEM スペクトルの項数 $\mathrm{m}$ による変化と FFT スペクトルの比較 
している様子が読み取れる。写真 -2 と図 -15 より、 2 箇所にピークをもつ AE 波形は、アルミナプレートにモ ルタルが薄く（約 $1 \mathrm{~mm} ）$ 付着した破壊面からの信号であ り、付着したモルタルが厚くなると、2 箇所にピークを もつ $\mathrm{AE}$ 信号は少なくなる。また、モルタルが付着して いない破壊面からは、ほとんど $\mathrm{AE}$ 信号が検出されな かった。
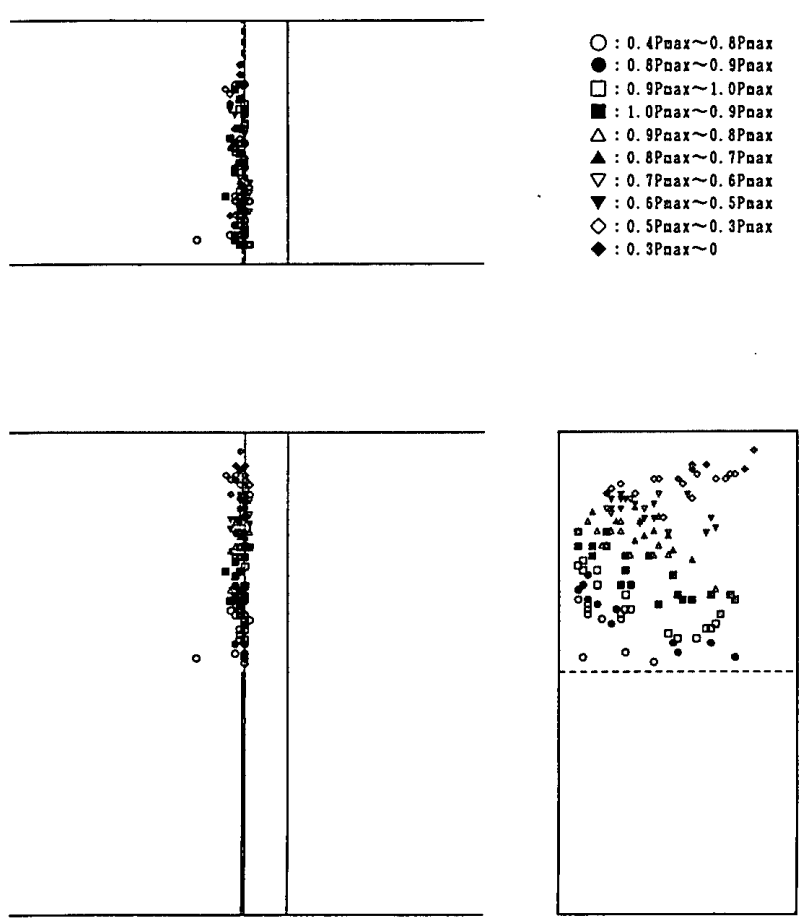

図ー15 高周波成分をもつ $\mathrm{AE}$ 波形による 三次元位置標定結果：PL-22B

（2）円柱型モデルコンクリート

円柱型モデルコンクリート（A1、A2、S3、S4、S5）の 三次元位置標定結果を、各荷重段階ごとに図ー16〜20に 示す。これらの図から、AE 信号はクラックの先端付近ば かりでなく、クラック先端よりかなり後方においても発 生し続けていることがわかる。これは、ダメージは受け ているが、応力を伝達できるいわゆる軟化領域の広がり を示していると考えられる。

同図の左下の図には、疑似粗骨材の位置と実際の破壊 経路（太い点線）を示している。AE はほほ破壊経路に 沿って発生しているといえる。 AE 信号がモルタル中で多 く、境界面で少ないのは、疑似粗骨材に付着したモルタ ルが少なかったためである（写真一2）。

なお、ほとんどの $\mathrm{AE}$ 波形のスペクトルは、150kHz 付 近に 1 箇所だけピークを持つ形となり、スペクトルパ ターンの分類による評価はできなかった。したがって、 $\mathrm{AE}$ 波形の初期微動（到達時間）が明確なデータのみ用い て、位置標定を行った。
下半分の試験体は、先に述べたように、モルタルが厚 く付着した破壊面となったため、2 箇所にピークを持つ $\mathrm{AE}$ 信号は少なく、モルタル試験体の A E 波形周波数特 性と同様、100-200kHzに 1 箇所のピークを持つA E 信号 となった。
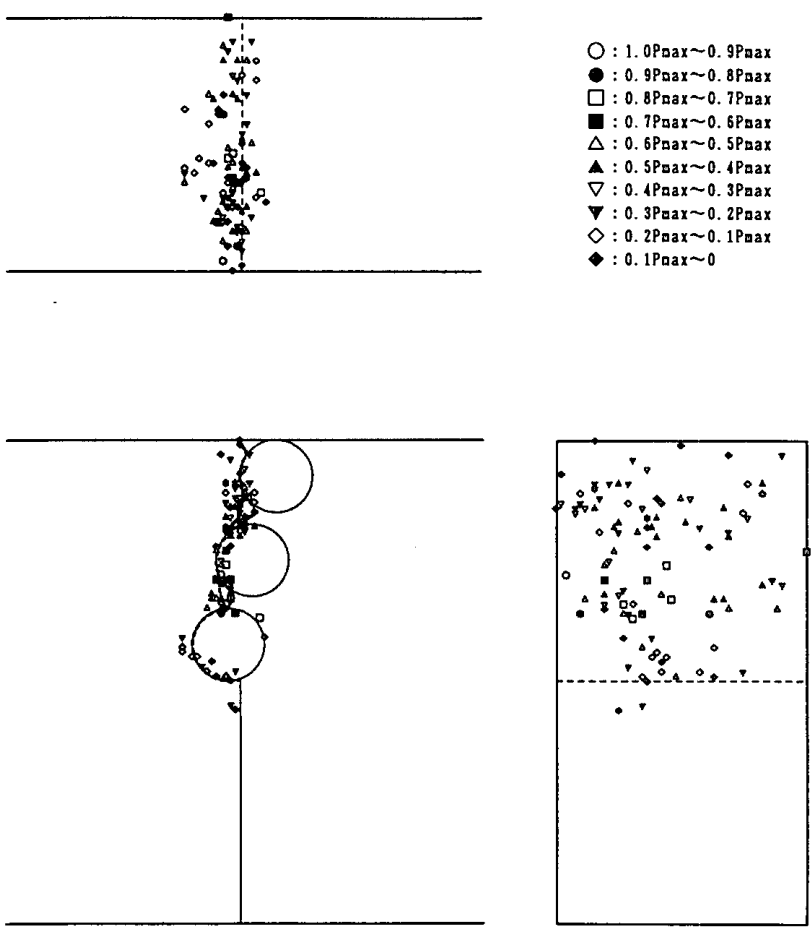

図-16 三次元位置標定結果と破壊経路：Al-2T
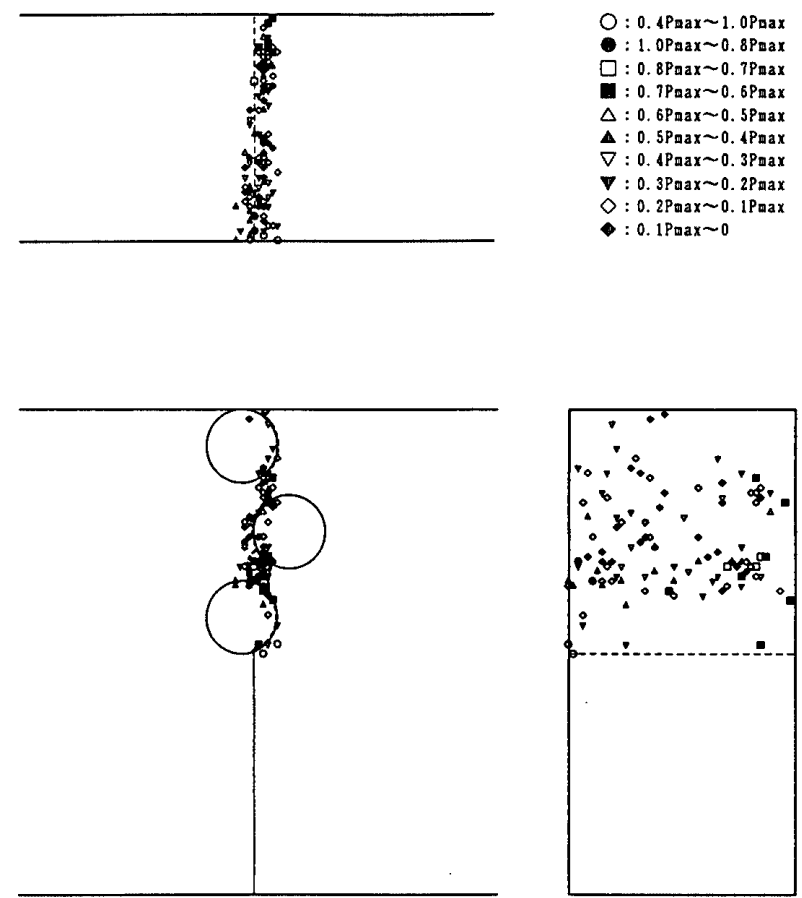

図-17 三次元位置標定結果と破壊経路：A2-2T 

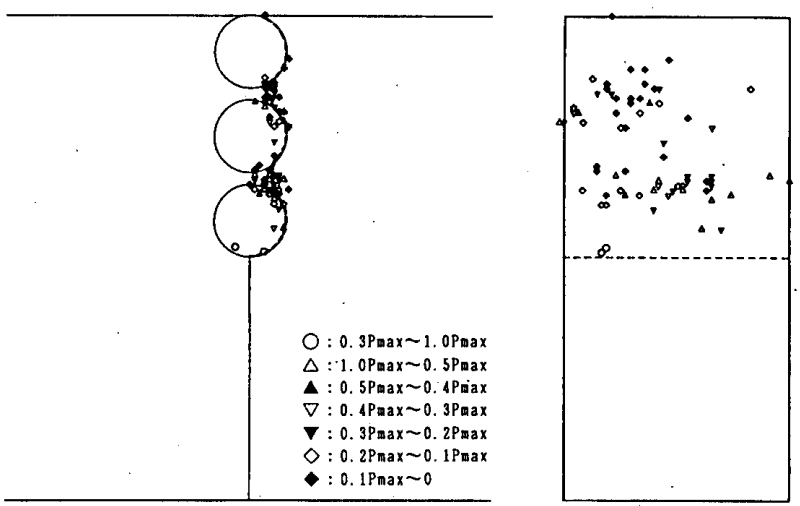

図-18 三次元位置標定結果と破壊経路：S3-2T

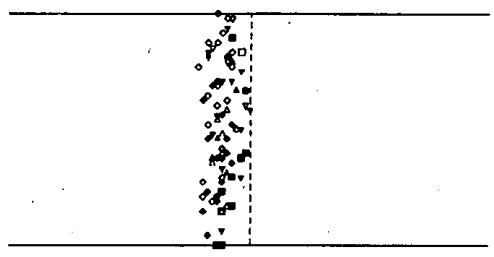

O: $1.0 P_{\max } \sim 0.9 \mathrm{Pmax}^{2}$ : $0.9 P_{\max } \sim 0.8 P_{\max }$ $: 0.8 P \operatorname{arax} \sim 0.7 \mathrm{Pax}$ $0.7 P_{\text {pax }} \sim 0.6 P_{\max }$ $\triangle: 0.6$ Pmax $\sim 0.3 P_{\max }$


$\nabla: 0.4 \operatorname{man} \sim 0.3 \operatorname{spax}$ $\nabla: 0.3 \max ^{2} \sim 0.21 \max$

$0: 0.2 P \max \sim 0.1 \mathrm{Pmax}$
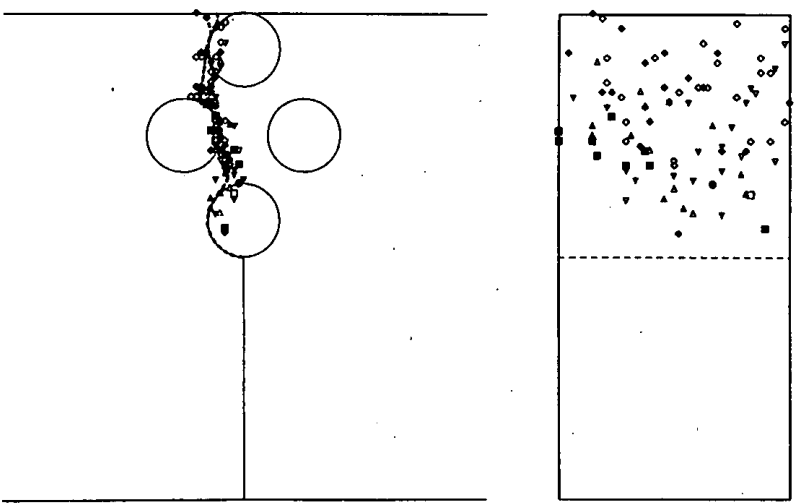

図-19 三次元位置標定結果と破壊経路：S4-2T
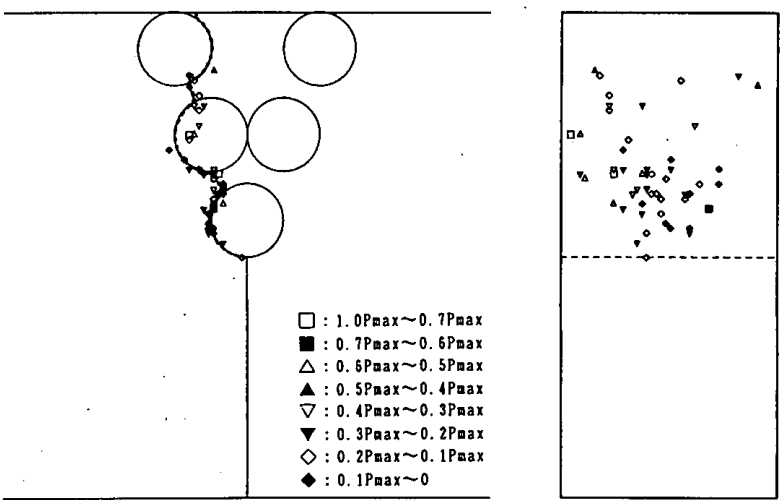

図-20 三次元位置標定結果と破壊経路：S5-2T
（3）モルタルおよびコンクリート

モルタルおよびコンクリートの三次元位置標定結果を、 各荷重段階ごとに図一21および 22 に示す。モデルコンク リートと同様に、AE 信号はクラックの先端付近ばかりで なく、クラック先端よりかなり後方においても発生し続 けており、軟化領域の広がりを示している。モデルコン クリートのような弱い境界面がないため、 $\mathrm{AE}$ 信号はより 多数発生している。コンクリートのAE発生位置は、モ ルタルほど一様ではなく、骨材位置に起因したと思われ る偏在が見られる。
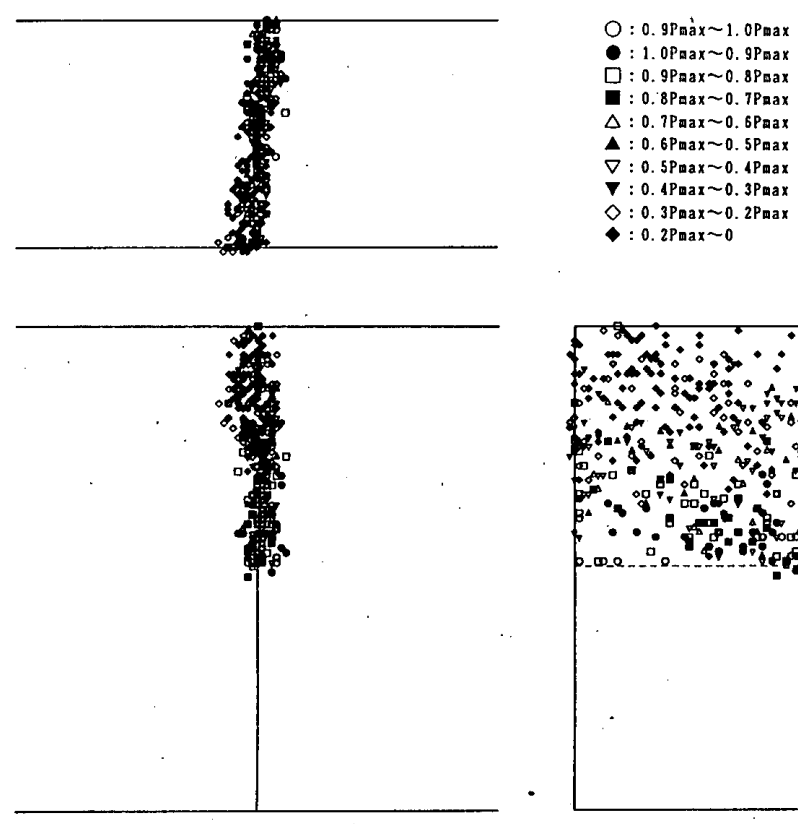

図-21 モルタル試験体の三次元位置標定結果：MT-B
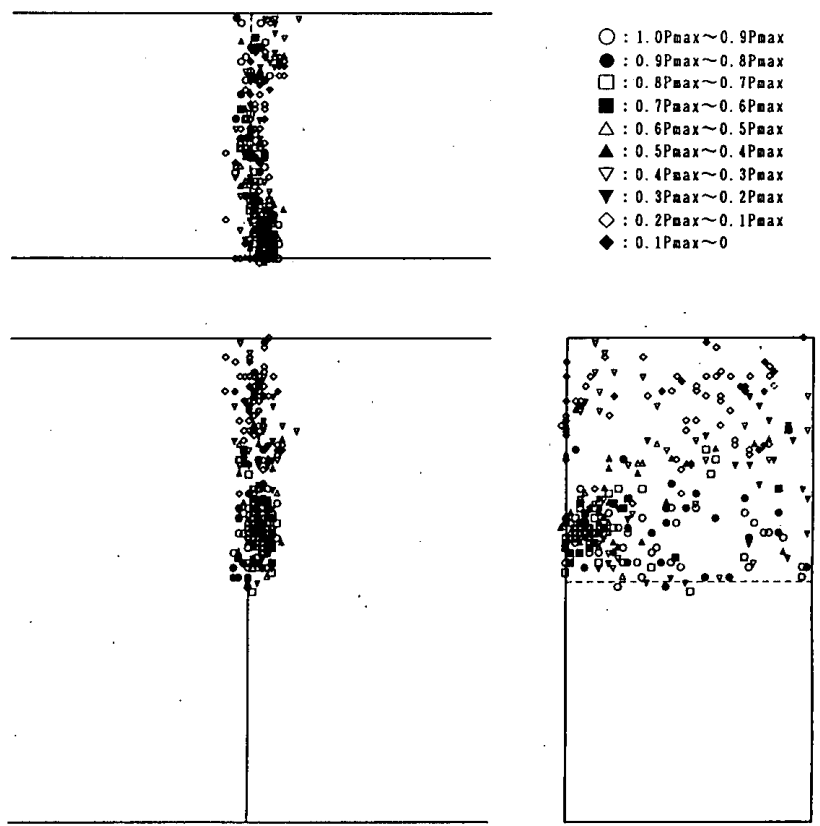

図－22 コンクリート試験体の三次元位置標定結果：CT-B 


\section{5.まとめ}

本論文では、円柱状の疑似粗骨材を含む簡単なモデル コンクリート試験体を用いて、クラック進展に及ぼす骨 材の影響を検討した。また、軟化領域の進展および大き さを推定するために、アコースティック・エミッション を計測し、3 次元位置標定およびスペクトル解析を行っ た。これから以下の結論を得た。

（1）モデルコンクリートに対して、定量的な考察を行う ためには、破壤面の詳細な検討が必要である。

（2）クラックが疑似粗骨材に到達した場合、骨材を迁回 してクラックがさらに進展するためには、より多く のエネルギーが必要になるため、最大耐力後におい て、上に凸の曲線がみられるようになる。このよう な骨材によるクラック拘束举動が多数重なり合うこ とによって、コンクリートのような最大耐力後の抵 抗力が得られる。

（3）本モデルコンクリート試験体は、ノッチ先端の疑似 粗骨材が初期䟝性に寄与するが、最大荷重の60〜 $80 \%$ 荷重で、疑似粗骨材とモルタルの境界面の損 傷が大きくなり、その境界面の則性が支配的になる ため、甽性の低下が生じ、不連続な曲線となる。

（4）プレート型モデルコンクリートの場合、 $\mathrm{AE}$ 波形の スペクトル解析 (MEM) によって、軟化頒域内の処 女破壊と考えられる 2 箇所のピークをもつ $\mathrm{AE}$ 波形 を識別することができ、その進展举動を示した。こ の $\mathrm{AE}$ 波形は、アルミナプレートにモルタルが薄く 付着した破壊面からの信号であった。

（5）円柱型モデルコンクリートの場合、スペクトル解析 による AE 波形の識別はできなかったが、到達時間 の明確な $\mathrm{AE}$ 波形を用いることによって、精度の良 い位置標定を行うことができた。

（6）モルタルおよびコンクリートの場合、モデルコンク リートのような弱い境界面がないため、 AE 信号は より多数発生し、最大耐力後の抵抗力も大きい。

（7） AE 信号はクラックの先端付近ばかりでなく、ク ラック先端よりかなり後方においても発生し続けて おり、軟化領域の広がりを示している。文献6)に示 すように、その領域をマイクロクラッキング領域と ブリッジング領域に分けた場合、クラック先端より 後方からの信号は、後者に対応するものと思われる。 したがって、AE 源の三次元位置標定により、軟化 領域の大きさを評価できる。
（8）本論文で行ったスペクトル解析では、プレート型モ デルコンクリート以外の A E 波形を分類することが できなかった。AE波形をより詳細に分類するため には、今後、原波形解析等を行っていく必要がある。

\section{参考文献}

1) 小林昭一、大津政康：アコースティック・エミッションのコン クリートエ学への応用： コンクリートエ学, Vol.16, No.7, pp.917,1978

2）山田和夫、小阪義夫：コンクリート中を伝ぱするアコース ティック・エミッションの減衰特性：材料, 第36巻, 第406号, pp.38-44, 昭和62年

3) A. Maji and S. P. Shah ; Process Zone and Acoustic-Emission Measurements in Cocrete, Experimental Mechanics, Vol.28, pp.27.33, 1988

4) P. Rossi, J. L. Robert, J. P. Gervais and D. Bruhat ; Acoustic emission applied to study crack propagation in concrete, Materials and Structures, Vol.22, pp.374-384, 1989

5) M. Ohtsu, M. Shigeishi, H. Iwase and W. Koyanagi ; Determination of crack location, type and orientation in concrete structures by acoustic emission, Magazine of Concrete Research, Vol.43, pp.127134,1991

6)策原保二, 安部武雄, 古村福次郎：ノッチ深さ, 載荷速度, 骨 材寸法, 水セメント比, 载荷法, 䖯生および材令がコンクリー

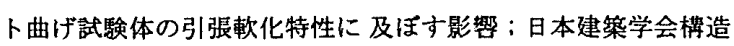
系論文報告集, 第442号, pp.13〜22, 1992

7) H. Duda; Grain-Model for the Determination of the Stress-CrackWidth-Relation, in Analysis of Concrete Structures by Fracture Mechanics, ed. by L. Elfgren and S. P. Shah, Chapman andHall, pp.88-96, 1991

8) 篠原保二、安部武雄、古村福次郎：アコースティック・エミッ ションのスペクトル分析による破壊進行領域の推定法；日本建 築学会大会学術講演梗概集A、PP.243 244, 1993

9) J. Ulrych and T. N. Bishop ; Maximum Entropy Spectral Analysis and Autoregressive Decomposition, Reviews of Geophysics and Space Physics, Vol.13, pp.183-200, 1975

10) D. E. Smylie, G. K. C. Clarke and T. J. Ulrych ; Analysis of Irregularities in the Earth's Rotation, Methods in Computational Physics, Vol.13, pp.391-430, 1973

11) 日野幹雄：スペクトル解析；朝倉書店, 1977

12) J. P. Burg ; Maximum Entropy Spectral Analysis, Proceedings of the 37th Meeting of the Society of Exploration Geophysicists, 1967

13) H. Akaike ; Fitting autoregressive models for prediction, Annals of the Institute of Statistical Mathematics, Vol.21, pp.243-247, 1969

14) H. Akaike ; Power spectrum estimation through autoregressive model fitting, Annals of the Institute of Statistical Mathematics, Vol.21, pp. $407-419,1969$

(1994 年 2 月 2 日原稿受理, 1994 年 10 月 14 日採用決定) 